https://doi.org/10.18485/iipe_postsovjet.2021.ch3

Наташа Томић-Петровић ${ }^{1}$

\title{
НУКЛЕАРНА БЕЗБЕДНОСТ НА ПОСТСОВЈЕТСКОМ И ЕВРОПСКОМ ПРОСТОРУ НАКОН КАТАСТРОФЕ У ЧЕРНОБИЉУ
}

\author{
Atomic energy, of and by itself, is neither good nor bad. \\ Whether it will play the role of "the evil giant or Prometheus \\ in the history of man" will depend on how men will use it, \\ what purpose they will give it.
}

(Вукасовић В.)

\begin{abstract}
Ancmpaкm: Став према различитим облицима коришћења нуклеарне енергије постао је један од главних узрока сукоба у спољној политици и међународним активностима држава уопште. Након несреће у Чернобиљу, MAAE је започела рад на свим аспектима нуклеарне одговорности с циљем побољшања основних конвенција и упостављања широког режима одговорности. Када је нуклеарна енергија у питању, еколошке катастрофе не познају границе и свако загађење животне средине једне земље или региона претња је за становништво много ширих области. Нуклеарна енергија, коју данас користи преко 50 земаља, обезбеђује око 10\% струје у свету из око 440 реактора, док је око 50 реактора у изградњи. Ефикасност правних и административних решења проблема које са собом носи мирољубива употреба нуклеарне енергије зависиће у значајној мери од одговарајућег прилагођавања релевантних правних области.
\end{abstract}

Кључне речи: безбедност, нуклеарна енергија, Чернобиљ, зрачење, заштита.

${ }^{1}$ Проф. др Наташа Томић-Петровић, редовни професор, Саобраћајни факултет Универзитета у Београду, e-mail: natasa@sf.bg.ac.rs 


\section{Увод}

Безбедност је стање у коме су искључени противправни акти, посебно они уз употребу физичке силе, којима се руше основна права грађана и основни елементи јавног, тј. друштвеног поретка. Јавна безбедност је у тесној вези са законитошћу, односно њеним остваривањем. У старој Југославији постојао је посебан закон о државној безбедности, Закон о основама система државне безбедности, ${ }^{2}$ као и посебни судови. Коришћење нуклеарне енергије било је уређено Законом о заштити од јонизујућег зрачења, ${ }^{3}$ и већим бројем подзаконских прописа. Данас је у Републици Србији на снази Закон о радијационој и нуклеарној сигурности и безбедности ${ }^{4}$ из 2018. године.

Војна неутралност и независна политика јачају позиције наше земље у свету. Стратешко партнерство са Русијом и Кином нам то гарантује, а главни спољнополитички правац Србије је улазак у Европску унију.

Уговор о контроли наоружања са Русијом, познат као „Нови Старт“5 продужен је за пет година (до 2026. године) и представља основу стратешке стабилности у свету. Почетком марта 2021. године Русија је Сједињеним Америчким Државама пренела своју верзију нове безбедоносне равнотеже у контроли наоружања. Међутим, Балтичко море које је окружено са осам земаља (Данска, Естонија, Летонија, Литванија, Немачка, Пољска, Шведска, Финска) претвара се убрзано у нови фронт сукоба између Русије и НАТО, односно Русије и САД. Да ли би у будућности могло да дође до употребе нуклеарног наоружања, јер је најсавременије наоружање Русије смештено непосредно уз Балтичко море?

Кина као и Сједињене Америчке Државе желе денуклеаризацију Северне Кореје. Као заједнички циљ Кина и Јужна Кореја имају денуклеаризацију Корејског полуострва и трајну политику успостављања мира.

\footnotetext{
2 „Службени лист СФРЈ “, број 15/84.

3 „Службени лист СФР“", број 54/76.

4 „Службени гласник” РС бр. 95/18.

5 "Нови Старт" обавезује Вашингтон и Москву да смање број распоређених стратешких бојевих глава на 1.550. Постојала је иницијатива да се и Кина прикључи договору о ограничавању атомског арсенала.
} 
У нашој земљи војна неутралност и независна политика јачају позицију Србије, док стратешко партнерство са Русијом и Кином гарантује територијални интегритет и суверенитет Србије. Такође Србија отвара војна изасланства у Црној Гори, Сирији и Либану, ради одбране државних и националних интереса.

\section{Нуклеарни акциденти}

Прва електрична централа на атомски погон подигнута је у СССР-у 1954. године, а три године касније и у САД. До 1976. године у свету је саграђено више од стотину нуклеарних електрана укупне снаге од око 80.000 MW (мегавата), а сваке три до четири године удвостручава се њихов капацитет. Највећа предност нуклеарних електрана је у великој концентрацији енергије у нуклеарном гориву, па нуклеарна електрана троши само неколико десетина тона горива годишње.

Критични акциденти су они на нуклеарним реакторима, који се догађају кад се довољно фисионог материјала, као што су обогаћени уранијум и плутонијум, нађу заједно. ${ }^{6}$

У непосредној близини нуклеарне електричне централе односно Атомског центра- Лос Аламос, у Новом Мексику, два акцидента десила су се 25. августа 1945. и 1. маја 1946. године на истраживачким реакторима и том приликом су два оператера умрла. Уследио је и нуклеарни критични акцидент 30. децембра 1958. године када је у истом научном центру један оператор умро од акутне радијационе болести. Новији акцидент датира од 11. маја 2000. године, када је избио пожар и спроведена евакуација особља електране.

Након несреће у нуклеарној електрани названој „Острво три миље” у Пенсилванији, 1979. године, у САД, пољски роботи употребљени су да прегледају, узму узорке и очисте ову контаминирану атомску централу. ${ }^{8}$ Критични акцидент догодио се 28. марта 1979. године, а узрок несреће је

\footnotetext{
${ }^{6}$ Стеван Марковић, Рајко Спаић, “Радијација и здравље”, Друштво за биомедицинско инжињерство и медицинску физику СР Југославије, Аранђеловац, 2001, стр. 100.

7 У коме је почетком 1945. године произведена прва фисиона нуклеарна бомба.

${ }^{8}$ Видети: Пол Кенеди: Припрема за XXI век, Београд, 1997, стр. 104.
} 
био квар на пумпама за снабдевање водом, што је узроковало топљење шипки са нуклеарним горивом (односно »топљење 150 тона тона тешког горњег дела језгра реактора«) и отпуштање радиоактивног криптона- 85. Утицај ове несреће на шири регион је непознат, зато што тада није вршено систематско мерење и праћење радиоактивности у свим околним државама. Ипак, после ове несреће многе земље су одустале или зауставиле изградњу нуклеарних електрана.

Треба поменути догађај у реактору Секвоја 1, у држави Тенеси, када је у фебруару 1981. године, радник, који је први дан на послу, без адекватне претходне обуке, отворио извор и са 110 хиљада галона радиоактивне воде контаминирао осам радника.

У румунској нуклеарној електрани »Чернавода « ${ }^{9}$ на Дунаву, која је удаљена око 150 км од главног града Букурешта, због високе температуре ваздуха (70 степени) активирани су противпожарни безбедносни системи и нуклеарка је затворена, али само привремено. Ово постројење покрива 20\% енергетских потреба Румуније и запошљава 2500 људи.

Такође је познат случај реактора у украјинској нуклеарној електрани „Ривне“ који се аутоматски искључио пошто га је ударио гром и оштетио електричне трансформаторе. Тада су се безбедносни системи аутоматски активирали, али није евидентирано изливање радиоактивних материја.

Средином августа 1999. године због квара у јединој суседној, бугарској нуклеарној централи, затворен је један реактор у Козлодују, а припремано је и затварање реактора број два, због рутинског годишњег система поправке. ${ }^{10}$ Иначе Козлодуј је објекат смештен на обали Дунава, 200 км од Софије и обезбеђује око половину потреба Бугарске у електричној енергији.

\footnotetext{
${ }^{9}$ Највећи је произвођач нуклеарног отпада у Румунији. Остатак отпада потиче од вађења руде уранијума, као и из нуклеарних истраживачких центара, из индустрије, медицине, пољопривреде. Национална Комисија за контролу нуклеарних активности, као владина организација одговорна је за развој, контролу и дозволе за нуклеарна постројења у суседној Румунији.

${ }^{10}$ Ова нуклеарна централа од укупно шест реактора, има четири реактора, совјетске производње, јачине по 440 мегавата, али и два модернија реактора снаге по 1.000 мегавата. Иначе у Козлодују раде само два реактора - пети и шести, јер је Бугарска из безбедносних разлога морала да затвори прва четири реактора, што је био услов за приступање Европској унији.
} 
Ове године Влада је одобрила извештај министарке за енергетику Петкове која предлаже изградњу новог, седмог нуклеарног реактора у старој нуклеарној централи Козлодуј.

Почетком октобра 1999. године дошло је до нуклеарног акцидента у Јапану, у фабрици за прераду уранијума у Токаимури, северозападно од Токија, када су услед неконтролисаног радиоактивног зрачења из фабрике, пошто су радници препунили контејнер са уранијумом, многи радници били изложени великим дозама зрачења.

У руским атомским централама у току 1999. године забележено је 90 инцидената, а најозбиљнији су били они у Курску и Кољску. Оба ова инцидента окарактерисана су као првостепени по међународној скали. У Русији је постојало 45 затворених градова у којима се становници баве научним и производним радом, везаним за неку опасну или безбедоносно осетљиву технологију. ${ }^{11}$

Средином фебруара 2000. године десио се нуклеарни инцидент у централи на нуклеарни погон "Indian Point 2", која се налази на око 60 км од Њујорка, на обалама реке Хадсон, када је из реактора неконтролисано исцурела извесна количина радиоактивне паре. Проглашен је аларм другог степена на скали од четири подеока, а представник компаније је известио да је ово први такав инцидент у протеклих 16 година рада, да је цурење паре било краткотрајно и да у околини није забележена радиоактивност изнад дозвољене границе.

Крајем априла 2001. године поново су украјински стручњаци у нуклеарној централи (South Ukraine) у месту Пивдено на југу Украјине

\footnotetext{
${ }^{11}$ Видети:"Руска реч", уредник и издавач Росијска Газета, Москва, дистрибутер „Политика“. Разлог посебног статуса града Озерска, у јужном Уралу, је то што се на територији града налази Федерално државно унитарно предузеће „Производна организација Мајак", где се производе радиоактивни изотопи и прерађује употребљено нуклеарно гориво. Стручњаци из прве гарнитуре радника „Комбината број 817“ (тако се раније звао „Мејак“) подвргавани су најстрожој селекцији. Живот у затвореном граду становници Озерска данас не схватају као ограничење, већ као привилегију. Модерни „Мајак“ рециклира употребљено нуклеарно гориво из Русије и многих других земаља и производи велики број ретких и важних радиоактивних изотопа, које преко 40 земаља света купује за медицинске потребе. Гориво које је 2010. године одвезено из нашег Нуклеарног института у Винчи, код Београда, отишло је на прераду управо у „Мајак“.
} 
регистровали инцидент, на срећу, означен као нулти (најнижи) ниво на међународној скали опасности (која је подељена на седам степена), јер је дошло до отицања водоника у систему хлађења генератора у једном реактору који је одмах одвојен од електричне мреже.

У фабрици „Чепецки“ за производњу обогаћеног уранијума, у руском граду Глазову 22. јуна 2001. године, дошло је до експлозије у којој су четири особе изгубиле живот, а три су повређене. Експлозија се догодила у сектору за пречишћавање калцијума, вероватно због непоштовања основних правила безбедности у фабрици. ${ }^{12}$

У нуклеарној електрани у Фламанвилу, у Француској 20. октобра 2001. године избио је пожар који је брзо саниран без повређених и без повећања радиоактивности у том региону.

У случају удеса, зависно од нивоа и могућих последица, проглашава се стање угрожености животне средине, у складу са законом. Међународна Агенција за атомску енергију развила је неколико пројеката везаних за развој националних планова за радијациона хитна дејства. Као резултат настао је План деловања у радијационим акцидентима, односно модел националног деловања у радијационим акцидентима првенствено за земље које немају нуклеарне електране, али обављају медицинске и индустријске активности које користе зрачење и радиоактивне материјале. План треба да послужи као основа за израду конкретних националних планова деловања у радијационим акцидентима и инцидентима у миру, а принципи које он садржи су универзални. Свака државна организација овлашћена за деловање у радијационом акциденту треба да развије и повремено проверава и ревидира свој властити план и детаљне процедуре деловања, које ће дати одговор дефинисан државним Планом.

Ипак, у уводу публикације „Радијација и здравље”13 аутори запажају да иако је оперативна сигурност постројења завидна и непрекидно се усавршава, државни и међународни надзор над њима перманентан а људско знање које рукује њиме близу идеалног, могућности масовне

12 Фабрика "Чепецки" је једна од највећих руских фабрика за производњу легура цирконијума и обогаћеног уранијума.

${ }^{13}$ Стеван Марковић, Рајко Спаић, „Радијација и здравље”, Друштво за биомедицинско инжињерство и медицинску физику СР Југославије, Аранђеловац, 2001. 
несреће континенталних размера, која би неминовно захватила и нас, нису елиминисане.

Недавно, председник Јужне Кореје Мун наредио је државним званичницима да размотре могућност да се против Јапана поднесе тужба Међународном суду за поморске спорове због испуштања радиоактивне воде из нуклеарне електране Фукушима у Тихи океан, упркос протестима јапанских рибара и организација за заштиту животне средине. Влада Јапана потврдила је да је донета одлука да се више од милион тона загађене, радиоактивне воде из нуклеарне електране Фукушима, оштећене у земљотресу и цунамију 2011, испусти у наредне две године у Тихи океан, ${ }^{14}$ након што се из воде уклоне штетни изотопи. ${ }^{15}$ Јужна Кореја је оштро протествовала поводом ове одлуке, а влада је позвала јапанског амбасадора у Сеулу Коичија Ајбошија на консултације током којих је договорен састанак међудржавних агенција поводом овог питања. Научници су упозорили да дугорочни штетни ефекти испуштања великих количина радиоактивне воде у море на живи морски свет нису познати.

Од Међународне Агенције за атомску енергију (MAAE) затражено је да избегава објављивање детаља о иранском нуклеарном програму. Иран апелује да се не објављују детаљи нуклеарног програма, пошто су Француска, Велика Британија и Немачка објавиле да Техеран нема веродостојан цивилни разлог за обогаћивање уранијума. У априлу ове (2021) године догодио се инцидент у иранском подземном постројењу за обогаћивање уранијума „Нетанц“. Иранске власти су за ову сајбер саботажу

14 ТТокијска електрокомпанија (ТЕРСО) која управља Фукушимом саопштила је да ће крајем наредне године бити попуњени капацитети за складиштење радиоактивне воде, а премијер Јапана Јошихиде Суга оценио је да је испуштање загађене воде у Тихи океан „најреалистичнија и неизбежна опција“. Из ТЕРСО је потврђено да капацитети за складиштење радиоактивне воде износе 1,37 милиона тона, као и да ће они бити пуни до јесени 2022. године.

${ }^{15}$ Стручњаци ТЕРСО и владе Јапана саопштили су да се из радиоактивне воде не може одстранити једино тритијум који, како је наведено, у малим количинама није штетан по животну околину и здравље људи, али се ниво свих осталих радиоактивних материјала у води могу смањити на дозвољени ниво. Дуго се спекулисало да ли ће влада донети овакву одлуку која је неколико година одлагана због протеста и из безбедносних разлога. Ипак, одлука је коначно донета на седници владе која је констатовала да је отпуштање загађене, радиоактивне воде у Пацифик - најбоље решење. 
оптужиле Тел Авив за „нуклеарни тероризам“, а то је свакако лош знак данас, када су у току преговори у Бечу о оживљавању Иранског нуклеарног програма, из кога су САД иступиле 2018. године. Стручњаци процењују да је због овог инцидента ${ }^{16}$ нуклеарни програм обогаћивања уранијума уназађен за девет месеци.

С обзиром на то да је тромесечни споразум о надзору између Техерана и Међународне Агенције за атомску енергију (MAAE) истекао, од 22. маја 2021. године Агенција неће имати приступ подацима прикупљеним унутар нуклеарних постројења, договорених споразумом. Следи наставак преговора о продужењу споразума о мониторингу.

У Босни и Херцеговини (БиХ) покренути су планови да од Брисела затраже помоћ у решавању проблема који имају са суседном државом Хрватском у вези са изградњом одлагалишта за радиоактивни отпад на Трговинској Гори, у општини Двор, на граници ове две земље. У питању је изградња одлагалишта за радиоактивни отпад из нуклеарке „Кршко“, упркос противљењу БиХ. Из Словеније је стигло упозорење стручњака да је ово подручје трусно и водопропусно, а после серије земљотреса у Хрватској, са епицентром недалеко од Трговинске Горе испољена је додатна узнемиреност грађана, док су еколози против одлагалишта спорног отпада у некадашњој касарни Југословенске Народне Армије (JHA) у Черкезовцу.

\section{Чернобиљска катастрофа - искуства и поуке}

Још дуго ће се памтити 26. април 1986. године када је реактор број 4 у нуклеарној електрани „Владимир Иљич Лењин“, у близини града Припјат (данашња Украјина), експлодирао у Чернобиљу загађујући велики део Европе, укључујући Украјину, Белорусију и Русију. ${ }^{17}$ Швеђани су несрећу у

${ }^{16}$ Ово није први инцидент у подземном постројењу, јер је пре 11 година откривен компјутерски вирус, а у јуну 2020. године десио се пожар.

${ }^{17}$ у 01.23 часа и 20 секунди дошло до велике контаминације читаве Европе и то краткоживећим (јод - 131, рутенијум - 105 и рутенијум - 106), као и дугоживећим (стронцијум - 90, цезијум - 134 и цезијум - 137) радионуклидима. Због немарности и дотрајалости уређаја дошло је до наглог отицања воде из система хлађења, температура је порасла на 3000 степени Целзијусових, што је узроковало топљење 
Чернобиљу регистровали својим апаратима у поподневним часовима 28. априла 1986. године, а тадашњем совјетском председнику Горбачову било је потребно чак 48 часова, односно два цела дана да званично обавести јавност да се удес десио. Недозвољено је одуговлачење са информацијама и ћутање или неадекватно предузимање свеобухватних постакцидентних, али и превентивних мера у току оштећења или удеса у нуклеарним постројењима, али и у току стандардног рада реактора.

Ублажавање последица експлозије покушало се бацањем из хеликоптера великих количина песка и земље са оловом и бором, који су познати као елементи који ограничавају неутронску радијацију. Тоне радиоактивног материјала данима су емитоване у атмосферу и скоро цела Европа је контаминирана радионуклидима чије су количине прелазиле дозвољене дозе за 100 до 10 хиљада пута. Наша земља је због оваквих акцидената донела Закон о забрани изградње нуклеарних електрана 1995. године. ${ }^{18}$

Град Кијев се 1995. године обавезао у договору са Групом седам најразвијенијих земаља света (Г7) да затвори Чернобиљ што се и догодило 15. децембра 2000. године. Реактор број 2 заустављен је 1991. године после пожара, док је реактор број 1 искључен 1996. године у оквиру међународног споразума. Трећи реактор нуклеарне електране у Чернобиљу, после пет месеци радова, поново је пуштен у рад 26. новембра 1999. године. На овом реактору, старе совјетске градње, извршена је поправка, провера и јачање система цеви у којима је, у току 1997. и 1998. године, откривено више стотина пукотина. Трећи реактор нуклеарне централе у Чернобиљу заустављен је 2. децембра, пошто је систем за хлађење лоше функционисао и откривена је пукотина у цевима са радиоактивном водом за хлађење.

У међувремену су власти у Украјини у више наврата саопштавале да нуклеарка у Чернобиљу може и даље да ради и после 2000. године, уколико Г7 на време не обезбеди обећану финансијску помоћ. Још у јануару 2000. године Украјина је расписала међународни конкурс за

омотача од цирконијума који се налазио око горива, а вода из турбина је дошла у контакт са радиоактивним материјалом. Усијана пара у реакцији са графитом, уранијумом и цирконијумом довела је до експлозије.

18 „Службени лист СРј”, број 12/95. 
изградњу објеката за складиштење чврстог радиоактивног отпада из нуклеарне електране Чернобиљ, који је финансирала Европска Комисија, а та нова постројења требало је да буду локализована поред објеката за прераду течног радиоактивног отпада из Чернобиља и да почну са радом у фебруару 2003. године.

Седам најразвијенијих земаља света и Европска унија потписале су још 1995. године са Украјином споразум о разумевању и обавезале су се да обезбеде огромна средства за санирање бетонског саркофага око атомског реактора који је експлодирао 1986. године и изазвао највећу катастрофу у историји цивилног коришћења атомске енергије, као и да кредитирају изградњу две нове нуклеарке, тј. нових енергетских извора у Украјини. То је изазвало полемике и жестоке протесте Зелених, тзв. „атомски рат“ и оптужбе против „финансирања новог Чернобиља“. Брзо обнављање саркофага је у интересу целе Европе, јер се на тај начин спречава евентуална нова нуклеарна штета, али пре свега да би се реализовали уговори о испоруци јефтине украјинске струје из нових нуклеарних електрана купцима у Европи, посебно у Баварској.

Украјински председник Кучма, 15. децембра 2000. године у 13 часова и 18 минута (по украјинском времену), издао је историјску наредбу и Чернобиљ је УГАШЕН. Из погона је искључен и последњи, трећи блок (који је Украјини обезбеђивао чак 5\% животно важне електричне енергије) вероватно најпознатије нуклеарке у свету, електране у Чернобиљу. Четврти блок експлодирао је 26. априла 1986. године и то је условило највећи акцидент у историји развоја нуклеарне технологије. На том подручју је после тога хиљаде људи, годинама, тихо умирало, многи су расељени, а земљиште је потпуно уништено. Зна се да је непосредно озрачен известан број радника примањем дозе од око 400 рема, од којих је четири месеца касније 31 озрачени радник умро. Постоје подаци да је дан после ове несреће ниво радијације у граду Припојту, крај Чернобиља био 1 рем/хектар. ${ }^{19}$

На дан 26. априла 2001. године, на петнаесту годишњицу од нуклеарне катастрофе у Чернобиљу, издато је званично саопштење Министарства унутрашњих послова Русије у Москви, да је тада погинуло око 10 хиљада

\footnotetext{
${ }_{19}$ Рем је старија јединица еквивалентне енергетске дозе јонизујућег зрачења. До 1980. године носила је ознаку кири.
} 
људи (такозвани „ликвидатори“, непосредни учесници отклањања последица трагедије), а више од 35 хиљада су остали инвалиди.

Савезни Комитет за рад, здравство и социјалну заштиту израдио је студију о нивоима радиоактивне контаминације човекове средине и озрачености становништва Југославије 1986. године услед хаварије нуклеарне електране у Чернобиљу. Процењује се да је током 1986. године на територији СФРЈ депоновано око 2,37\% укупно емитоване радиоактивности (не рачунајући племените гасове) из нуклеарне електране у Чернобиљу, односно око 5\% емитованог Ј 131 и око 10\% емитованог Ц 137. ${ }^{20}$ Тек крајем децембра 1996. године наши стручњаци објавили су своје налазе у вези последица Чернобиљске катастрофе у Србији. Наша земља, иако без нуклеарних постројења, налази се у нуклеарном обручу.

Без обзира на мере заштите и сигурности, реактори у електранама и при нормалном раду испуштају одређену количину радиоактивног материјала, који се из године у годину смањује. ${ }^{21}$

\section{Нуклеарне електране - реалност и перспективе}

Развој нуклеарних наука у свету постао је за неке симбол прогреса и инструмент превазилажења заосталости, док је за друге још увек симбол власти и силе, један од инструмената економске доминације. Природни ресурси нису равномерно распоређени у свету и постоје државе које немају могућност да бирају. Наша земља није у потпуности искористила природне ресурсе и не мора да жури са градњом нуклеарне електране. Градња нуклеарних електрана снижава трошкове производње електричне енергије у систему и она повољно утиче на чување енергетских извора. ${ }^{22}$

Државе-чланице које немају постројења за производњу нуклеарне енергије за сада су напустиле планове одлагања сопственог радиоактивног

\footnotetext{
20 Јовановић М, Биомедицински и социолошки значај акциденталног озрачења људи, Београд, 1989, стр. 26 и 27.

${ }^{21}$ Видети: Марковић С, Спаић Р, „Радијација и здравље”, Друштво за биомедицинско инжињерство и медицинску физику СР Југославије, Аранђеловац, 2001, стр. 75.

${ }^{22}$ Анастасијевић П, Мојовић љ, Развој нуклеарних електрана, „Нуклеарна енергија”, број 5, Београд, 1966, стр. 11.
} 
отпада. Три државе (Италија, Холандија и Велика Британија) одлучиле су да одложе одлагање свог отпада високе радиоактивности за време које варира од најмање 50 до више од 100 година.

Преко 50 земаља у свету користи нуклеарну енергију у око 220 истраживачких реактора. У изградњи је још око 50 реактора, што одговара приближно 15\% постојећег капацитета. Дванаест земаља у 2019. години произвело је најмање четвртину електричне енергије из нуклеарне енергије. Француска отприлике три четвртине електричне енергије добија из нуклеарне енергије, Словачка и Украјина више од половине, док Мађарска, Белгија, Шведска, Словенија, Бугарска, Швајцарска, Финска и Чешка добијају једнутрећину или више. Јужна Кореја обично више од $30 \%$ електричне енергије добија из нуклеарне енергије, док је у САД-у, Великој Британији, Шпанији, Румунији и Русији око једне петине нуклеарна електрична енергија.

Свакодневно се у свету повећава број извора нуклеарне енергије, ничу нови нуклеарни реактори, подижу се нуклеарне централе, изграђују акцелератори и друге нуклеарне машине које служе за научна истраживања или за производњу енергије.

Кина је предвиђала да удео нуклеарних електрана у укупној производњи електричне енергије буде повећан са $1 \%$ на 3\% у 2006. и 5\% у 2020. години. У оквиру петогодишњег плана (2001-2005) била је предвиђена изградња шест до осам нових централа од 1000 мегавата, уз постојеће три и још четири у изградњи. Кина је овладала технологијама за изградњу нуклеарних електрана, ${ }^{23}$ иако су инсталирани капацитети нуклеарних електрана много мањи од светског просека и износили су око 1\% укупне годишње производње електричне енергије у Кини. До позних 70-их, Кина је претекла Француску и Британију и постала трећа светска нуклеарна сила. ${ }^{24}$

у Јапану се из нуклеарних електрана добијало више од трећине електричне енергије. Пошто не располаже природним ресурсима, за ову

\footnotetext{
23 Јуна 2000. године Кина је извезла у Пакистан нуклеарни реактор од 300 мегавата, који је уграђен у нуклеарну централу „ЧАШМА“ у Пакистану, која је почела да се гради још 1993. године. Поред овога кинеска национална нуклеарна корпорација извозила је нуклеарно гориво и мини реакторе и у друге земље.

${ }^{24}$ Видети: Пол Кенеди, Припрема за XXI век, Београд, 1997, стр. 204.
} 
земљу нуклеарна енергија је од изузетног значаја. Иначе, Јапан има 35 нуклеарних реактора, ${ }^{25}$ који енергијом снабдевају 37\% становништва. После несреће у Фукушими, јапанска електро-енергетска предузећа одлучила су да не модернизују застареле реакторе и централе, већ да их потпуно расходују. Двадесет и четири реактора, или 40 одсто од укупног броја у Јапану, предвиђено је за затварање или је већ почела припрема за њихово трајно искључивање. Међу њима су и четири јединице уништене цунамијем у постројењу Фукушима Даи-ићи. Нуклеарни отпад из Јапана транспортује се бродовима на прераду у Француску и/или Британију, а потом се чува у привременом складишту у месту Рокашо у провинцији Аомори. Стога је невероватан податак да у овој земљи, која је доживела разарања у Хирошими и Нагасакију, чак и не постоји организовани покрет еколога и противника примене нуклеарне енергије.

У Белорусији је прва нуклеарна електрана пуштена у погон новембра 2020. године.

Чешки регулатор за нуклеарну енергију одобрио је у близини села Дуковани, у централном делу земље, изградњу два нова нуклеарна реактора. Након процене пројекта, која је трајала годину дана, одобрено је проширење нуклеарке Дуковани која се налази готово 100 километара северно од аустријске престонице Беча и око 200 километара источно од немачког града Пасауа, према Закону о атомској енергији, с обзиром на то да нису утврђене чињенице које би спречиле проширење нуклеарке. Тренутно су у нуклеарки у функцији четири реактора старија од 30 година, укупног капацитета производње 2.040 мегавата електричне енергије, а струја произведена у тој нуклеарки тренутно покрива око петину укупних чешких потреба за електричном енергијом. Према плановима чешке владе, први нови реактор би требало да се прикључи на електромрежу између 2035. и 2037. године, а трошкови изградње се процењују на 7,5 милијарди евра. Влада у Прагу жели да до 2040. године производи више од половине струје из нуклеарне електране. Ипак, еколошки активисти, посебно из оближње Аустрије, дуже време оштро критикују планове о проширењу нуклеарке Дуковани, при чему упозоравају да њена сигурност у случају потреса није примерена и позивају на прелазак на обновљиве изворе енергије.

25 Податак MAАЕ из маја 2020. године. 
Казахстан као водећи произвођач уранијума има 12\% светских резерви уранијума, док Киргистан располаже резервама уранијума и снабдевао је Русију у прошлости.

Украјина поседује 15 оперативних нуклеарних реактора, а у 2019. години нуклеарна енергија је давала више од половине, тј. 54\% електричне енергије у земљи, док Русија са 38 реактора добија око једну петину електричне енергије из нуклеарних извора.

Априла 2001. године, ${ }^{26}$ после дугогодишњег противљења јавности, свет је обишла вест да је у Русији прорадила „нова руска нуклеарка“. Прва руска нуклеарна електрана после совјетске ере почела је да испоручује електричну енергију јужним регионима у земљи. После две деценије од почетка градње, уследио је пробни рад у фебруару 2001. године, а потом је са 10\% капацитета пуштен у рад први реактор атомске централе „Ростов“. Министарство за атомску енергију планирало је да до 2010. године пусти у рад 10 енергетских блокова укупне снаге 10 мегавата, док ће се из експлоатације искључити 15 енергетских блокова прве и друге генерације, који ће бити замењени са 34 нова. У Русији се верује да се овде не може десити реприза Чернобиља. Такође је планирано да се тадашњих 14\%, а данашњих 19\% електричне енергије, која се производи у нуклеарним електранама, до 2030. године удвостручи, односно подигне на 30\%.

Интересантно је да се у граду Сарову налази се Руски федерални нуклеарни центар у коме постоји Музеј атомског оружја, једини те врсте у свету.

Са друге стране, економска, регулаторна и политичка разматрања довела су до превременог затварања неких енергетских реактора. Литванија је затворила свој последњи нуклеарни реактор, који је производио 70\% електричне енергије, крајем 2009. године

\section{Правни оквир за заштиту при коришћењу нуклеарне енергије}

Новија међународноправна решења инсистирају на коришћењу нуклеарне енергије у конструктивне сврхе у универзалним светским

\footnotetext{
${ }^{26}$ У Русији је у том периоду у функцији било 29 енергетских блокова.
} 
размерама. То утиче на манифестовање међународноправне основе ове сарадње у проглашавању и спровођењу циљева и принципа међународног права који одговарају свим државама, независно од степена њиховог развоја на нуклеарном пољу.

Ефикасност правних и административних решења проблема које са собом носи мирољубива употреба нуклеарне енергије зависиће у значајној мери од одговарајућег прилагођавања релевантних правних области, тако да правне норме не буду застареле у поређењу са научним чињеницама и стварношћу. Потребна је размена информација, сарадња стручњака у заједничким подухватима у току научноистраживачког рада и технолошког развоја.

Несрећа у Чернобиљу показала је ризике мирољубивог коришћења нуклеарне енергије. Такође је указала на недовољност постојећег међународног режима нуклеарне безбедности. Поверење јавности у нуклеарну индустрију било је пољуљано и због тога су одмах предузете мере да би се оно повратило. MAAE је за врло кратко време створила две конвенције које су пет месеци после несреће отворене за потпис: Конвенција о раном обавештавању о нуклеарној несрећи и Конвенција о помоћи у случају нуклеарне несреће или радиолошке хитности. Обе конвенције су убрзо ратификовале многе државе. Ипак, утицај ових конвенција на актуелну нуклеарну безбедност био је ограничен зато што су се оне бавиле једино последицама нуклеарних несрећа, а не њиховом превенцијом. Одређивање подручја примене Конвенције о раном обавештавању ${ }^{27}$ оставља широке могућности процене држави у којој се несрећа десила и стога доводи у питање саму обавезу обавештавања. Конвенција о помоћи у случају нуклеарне несреће има шире подручје примене, али не ствара аутоматски право на помоћ држави која то тражи. Према члану 2 /3/ Конвенције држава чланица којој је упућен захтев за помоћ обавезна је само да брзо одлучи да ли је у могућности да захтевану помоћ пружи. Поред тога, била је појачана примена различитих

\footnotetext{
${ }^{27}$ Ограничено је на несреће у којима се дешава или ће се вероватно десити испуштање радиоактивног материјала и које за резултат имају, или могу имати, међународно прекогранично испуштање које би могло бити од значаја за радиолошку безбедност друге државе. (Видети: члан 1/1/ Конвенције о раном обавештавању о нуклеарној несрећи)
} 
мултилатералних и билатералних међународних програма техничке помоћи намењених побољшању безбедности нуклеарних постројења.

Више од осам година након катастрофе у Чернобиљу, Конвенција о нуклеарној сигурности Генералне Конференције MAAE отворена је за потпис с циљем да спречи дешавање таквих несрећа у будућности. Ова Конвенција садржи прве светске обавезујуће међународне стандарде о постављању, нацрту, изградњи и раду у нуклеарним електранама. Ипак, оквир Конвенције је сужен на најмању могућу категорију нуклеарних електрана. Овде не спадају војна постројења, истраживачки реактори и постројења посебно намењена третману и складиштењу радиоактивног отпада. Забрињава инсистирање Конвенције да је одговорност за нуклеарну безбедност ствар државе у којој се нуклеарно постројење налази. Од држава чланица захтева се да консултују и обавесте друге стране уговорнице на које ће предложено нуклеарно постројење бити од утицаја, али Конвенција не обезбеђује да се њихове примедбе морају узети у обзир.

Када је то потребно, у оквиру Конвенције, уговорна страна осигураће сва оправдана практична побољшања као ствар хитности у циљу унапређења безбедности нуклеарног постројења. Ако се ово не може постићи, у најкраћем року требало би спровести планове затварања нуклеарног постројења. При одређивању времена затварања може се узети у обзир целокупна енергетска ситуација и могуће алтернативе, као и друштвени, еколошки и економски утицај. ${ }^{28}$ Пошто су фактори које треба узети у обзир при одређивању тренутка затварања веома бројни, држава чланица практично располаже неограниченим дискреционим правом да доносе овакву одлуку.

Услови Конвенције у суштини су одређени оним што су велике нуклеарне силе (Француска, Велика Британија и САД) биле спремне да прихвате. Француска и Велика Британија супротставиле су се идеји и зато обавезујући међународни стандарди нуклеарне безбедности нису усвојени. Изгледа да је њихова главна брига била да сопствене нуклеарне индустрије не подвргну озбиљном међународном прегледу и да не буду изложене финансијским потраживањима других држава чланица. Остале

${ }^{28}$ M. Gavouneli, N. Skourtos, International Environmental Law, Summer Session, Rhodos, 1997, p. 135. 
државе морале су да се сложе са овим приступом, јер не би имало смисла усвојити конвенцију којој би велике силе одбиле да приступе. Очекивало се да недостаци ове Конвенције буду превазићени усвајањем Конвенције о безбедности управљања радиоактивним отпадом.

Конвенција о физичкој заштити од нуклеарног материјала усвојена у Бечу 26. октобра 1979. године (ступила на снагу фебруара 1987. године), ${ }^{29}$ захтева од уговорних страна да обезбеде заштиту од нуклеарних материјала унутар њихове територије или у иностранству на њиховим бродовима, или ваздухопловима у току обављања међународног транспорта. Овом Конвенцијом успоставља се оквир који омогућава државама да примене санкције против лица која учине кривична дела везана за нуклеарне материјале. Конвенција о физичкој заштити од нуклеарног материјала има за циљ да стварањем јединствених правила отклони потенцијалне опасности од незаконитог узимања и коришћења нуклеарног материјала. Њоме се олакшава међународни превоз нуклеарног материјала, а универзални стандарди Конвенције замењују потребу склапања посебних билатералних споразума. Прва Конференција за ревизију, којој је присуствовало 35 држава потписница, одржана је у Бечу 1992. године када је изражена пуна подршка Конвенцији и апеловало се на све државе да јој приступе. Констатовано је да Конвенција пружа одговарајући оквир за међународну сарадњу у заштити, обнови и враћању украденог нуклеарног материјала и у примени кривичних санкција против лица која чине кривична дела у вези са нуклеарним материјалом. Измене и допуне ове Конвенције усвојене су 2005. године, а у нашој земљи су потврђене истоименим Законом 2016. године. ${ }^{30}$

Након несреће у Чернобиљу, МAAE је започела рад на свим аспектима нуклеарне одговорности с циљем побољшања основних конвенција и упостављања широког режима одговорности. Током 1988. године, као резултат заједничких напора МАAЕ и ОЕЦД-а, усвојен је Заједнички протокол (Joint Protocol) који се односи на примену Бечке и Париске Конвенције и успоставља везу између Конвенција уједињујући их у јединствен шири режим одговорности.

${ }^{29}$ До септембра 2020. године било је 162 стране-уговорнице ове Конвенције, 161 држава и Еуратом.

30 „Службени гласник РС - Међународни уговори” бр. 4/2016-5. 
Одговорност за нуклеарну штету међународне одредбе успостављају у четири споразума. То су: 1. Бечка конвенција о грађанској одговорности за нуклеарну штету из 1963.године; 2. Париска Конвенција о одговорности према трећим лицима у области нуклеарне енергије из 1960, допуњена Протоколима 1964. и 1982. године, док Протокол из 2004. године још није ступио на снагу; 3. Бриселска Конвенција са амандманима из 1964. и 1982. године, и 4. Заједнички Протокол из 1988. године, који је ступио на снагу 1992. године. ${ }^{31}$

Бечка Конвенција унела је ред предвиђајући да њене одредбе, као и одредбе националних нуклеарних закона морају бити примењене без дискриминације засноване на националности, пребивалишту или боравишту. ${ }^{32}$ Париска Конвенција била је први међународни споразум који је обезбедио режим одговорности при мирољубивом коришћењу нуклеарне енергије. Најстарија је Конвенција, са ограниченим европским дометом и ограничена на копнене нуклеарне инсталације. Доношење ове Конвенције био је израз потребе да се постигне одговарајућа заштита трећих лица од штете коју изазива нуклеарна индустрија или употреба нуклеарних постројења (нпр. експлозија атомског реактора). Сврха ове Конвенције је усклађивање националних законодавстава с обзиром на одговорност према трећим лицима и осигурање од атомских ризика и успостављање режима одговорности и компензација у случају нуклеарног инцидента. Конвенција се генерално примењује само на нуклеарне инциденте који се десе и ако је штета претрпљена на територији страна-уговорница. Конвенција предвиђа апсолутну одговорност корисника нуклеарне енергије или превозника нуклеарног материјала и одређује горњи и доњи лимит за накнаду штете (15 и 5 милиона долара). Државама-потписницама је дозвољено да природу, форму и домашај компензације одређују саме у оквиру лимита, уз напомену да ће праведна расподела накнаде бити утврђена према националном закону. Значај Конвенције је доследна примена принципа апсолутне одговорности, која може да служи као пример у међународном праву, али је њен значај умањен због регионалног карактера, док је њена униформност жртвована увођењем флексибилног система лимита, односно давањем велике надлежности националним законима. Признајући да у многим

\footnotetext{
31 Према подацима МАAЕ из јула 2020. године Протокол има 31 страну уговорницу.

${ }^{32}$ Albonetti A, Belser W. E, Berger R i ostali, Droit nucléaire Européen, Paris, 1968, str. 81.
} 
случајевима претрпљена штета може да премаши одговорност оператера, већина држава-уговорница Париске Конвенције ратификовала је Бриселску допунску Конвенцију 1963. године.

Септембра 1997. године учињен је значајан корак у побољшању режима одговорности за нуклеарну штету. На дипломатској конференцији у седишту MAAE у Бечу од 8-12. септембра 1997. године, усвојен је Протокол за измену Бечке Конвенције о грађанској одговорности за нуклеарну штету из 1963. године, који данас има 15 страна уговорница, као и Конвенција о допунској накнади за нуклеарну штету. Овај Протокол одређује могућу границу одговорности оператера на најмање 300 милиона специјалних права вучења (око 400 милиона америчких долара). Конвенција о допунској накнади одређује додатне суме које се обезбеђују кроз доприносе држава уговорница, на основу постигнуте нуклеарне моћи и стопе вредновања Уједињених нација, а могу јој приступити све државе без обзира да ли су стране потписнице неке од постојећих конвенција о нуклеарној одговорности или имају нуклеарна постројења на својој територији. Између осталог, Протокол садржи бољу дефиницију нуклеарне штете (која сада узима у обзир концепт еколошке штете и превентивних мера), ширећи географски домашај Бечке Конвенције и продужавајући рок у коме се може захтевати накнада штете због смрти и телесне повреде. Такође, обезбеђује надлежност обалних држава над актима изазивања опасности од нуклеарне штете током транспорта.

Септембра 1990. године Генерална конференција Међународне агенције за атомску енергије усвојила је Правилник о међународном прекограничном кретању радиоактивног отпада. Правилник је саветодаван, пружа смернице државама у вези са међународним прекограничним транспортом бродом радиоактивног отпада, одређујући да свака држава треба да предузме одговарајуће кораке, неопходне за осигурање управљања и одлагања на безбедан начин радиоактивног отпада унутар њене територије и под њеном јурисдикцијом или контролом, као и заштиту здравља људи и заштиту животне средине. Смернице су засноване првенствено на претходном обавештавању и сагласности држава-пошиљалаца, држава-прималаца и држава транзита. ${ }^{33}$

\footnotetext{
${ }^{33}$ Видети: Preventing the transboundary movements of hazardous wastes in the
} Mediterranean region, VII Ordinary Meeting of the contracting Parties to the Convention 
Иако Правилник не забрањује прекогранично кретање радиоактивног отпада, такође, признаје суверено право сваке државе да забрани пренос радиоактивног отпада у/из или преко своје територије.

Ипак, потписнице Ломе IV Конвенције 1989. године схватиле су узалудност покушаја „контроле” или управљања превозом радиоактивног отпада и позвале на комплетну забрану увоза радиоактивног отпада у 68 афричко-карипско-пацифичких држава, као део њихове забране трговине отпадом. ${ }^{34}$

\section{Заједничка конвенција о безбедности управљања истрошеним горивом} и радиоактивним отпадом, први је глобални међународноправни инструмент, који регулише област управљања истрошеним горивом и радиоактивним отпадом, насталим из цивилних нуклеарних реактора, али и из војних и одбрамбених програма (ако се и када такви материјали трајно пребаце у оквир цивилних програма или када се декларишу као истрошено гориво или радиоактивни отпад према Конвенцији). ${ }^{35}$

У оквиру мера за јачање међународне сарадње у области коришћења нуклеарне енергије, зрачења и безбедности отпада 3. октобра 1997. године у току IX пленарног састанка МАAЕ усвојена је Резолуција ${ }^{36}$ којом је као обавеза држава уговорница одређена примена Заједничке Конвенције о безбедности управљања истрошеним горивом и радиоактивним отпадом, која је отворена за потпис 29. септембра 1997. године, а ступила је на снагу 18. јуна 2001. године, а у Србији марта 2018. године. ${ }^{37}$ Обавезе страна уговорница највећим делом засноване су на принципима документа “Принципи управљања радиоактивним отпадом" МААЕ из 1995. године што подразумева обавезе изградње и неговања законодавства у овој области, обезбеђења адекватне заштите појединаца, друштва и животне

for the Protection of the Mediterranean Sea against Pollution and its related protocols, Cairo, Egypt, 1991, p. 41.

34 Видети: члан 39. Конвенције.

35 Драгољуб Тодић, "Нуклеарна безбедност и радиоактивни отпад", Законодавство ЕУ у области заштите животне средине и земље у транзицији, у зборнику радова са XXV Саветовања са међународним учешћем “Заштита ваздуха '97", Београд, стр.84.

${ }^{36}$ Овом Резолуцијом апелује се на државе да потпишу, а потом и ратификују Конвенцију да би што пре могла да ступи на снагу.

${ }^{37}$ До марта 2021. године ова Конвенција има 84 стране уговорнице. 
средине од радиолошких и других опасности, затим обавезе у вези са прекограничним кретањем истрошеног горива и радиоактивног отпада као и предузимање потребних корака за безбедно управљање некоришћеним херметички затвореним изворима. ${ }^{38}$

Поред међународних уговора на које је посебно указано, постоје и други међународни уговори које би ваљало имати у виду: например Конвенција о заштити радника од јонизујућих зрачења (Женева, 1960. године), Конвенција о грађанској одговорности у области поморског транспорта нуклеарног материјала (Брисел, 1971. године), Конвенција која се односи на професионалну сигурност и здравље и радну средину (Женева, 1981. године) и Конвенција о процени утицаја на животну средину у прекограничном контексту (Еспо, 1991).

Треба разумети да одговорност за међународну штету животној средини укључује концепт одговорности државе за кршење међународног права, али такође и одговорност за штету која настаје из активности коју међународно право дозвољава; то је објективна и безусловна одговорност за активности за које је држава одговорна.

Мирољубиво искоришћавање нуклеарне енергије нужно захтева доношење детаљнијих прописа којима ће се прописати и одговарајуће обавезе, како за кориснике нуклеарних постројења, тако и за оне који на било који начин долазе у контакт са нуклеарним постројењима. ${ }^{39}$

Оно што је довело до промене става било је схватање да Чернобиљ није био усамљен случај и да би слична катастрофа могла да се деси у свако доба на неком другом нуклеарном постројењу у Централној или Источној Европи. Графитни реактори, слични оном у Чернобиљу наставили су да раде у Украјини и Русији. Ове нуклеарне електране имају озбиљне пропусте и несреће различитог степена опасности се често дешавају. Међутим, нуклеарна енергија као извор јефтине енергије има чврст ослонац у земљама Централне и Источне Европе, тако да предлог за престанак рада ових постројења делује нереално.

38 Драгољуб Тодић, „Нуклеарна безбедност и радиоактивни отпад”, Законодавство ЕУ у области заштите животне средине и земље у транзицији, у Зборнику радова са XXV Саветовања са међународним учешћем „Заштита ваздуха '97”, Београд, стр. 86.

${ }^{39} \mathrm{C}$. Поповић, О правном регулисању смештаја радиоактивног отпада и другим проблемима нуклеарног права, Београд, 1990, стр. 228. 


\section{Закључна разматрања}

Најновија међународна правна решења инсистирају на употреби нуклеарне енергије у конструктивне сврхе универзалних светских размера. То утиче на испољавање међународноправних основа сарадње у проглашавању и спровођењу циљева и принципа међународног права који одговарају свим земљама, без обзира на степен њиховог развоја у нуклеарној области.

Специфичност нуклеарних реактора је да садрже велике количине радиоактивних материјала и стога су објективна опасност, као и то да је штетни утицај радиоактивности на људско здравље и окружење разлог за велику опрезност и бригу да сигурност нуклеарних реактора буде обезбеђена. Неопходна је научна, техничка и индустријска сарадња у раду са нуклеарном енергијом, као и беспрекорна организација рада у оквиру једне нуклеарне електране, односно у нуклеарним постројењима и око њих. Такође, нужан је константан рад на побољшању сигурности нуклеарних електрана и широко заснованом информисању о свим аспектима и последицама могућих догађаја на тим постројењима.

Одуговлачење са информисањем јавности или касно (неправовремено) предузимање свеобухватних, правовремених или постакцидентних мера при раду, хаваријама или удесима у нуклеарним електранама - не би никоме користило.

Русија стално иде напред са плановима за ширу улогу нуклеарне енергије, укључујући развој нове технологије реактора, док су извоз нуклеарних добара и услуга главна руска политика и економски циљ.

Данас се велике силе отимају за благо леденог острва Гренланда, највећег неразвијеног налазишта све траженијих ретких хемијских елемената на свету. Осмогодишња борба 1.500 становника Нарсака, на јужном делу Гренланда против отварања рудника уранијума, уродила је плодом, јер нова Влада планира да заустави отварање рудника уранијума, односно да се заустави рударски пројекат Кванефјелд и од загађења радиоактивном прашином сачува животна средина.

Иако је прошло 35 година од несреће у Чернобиљу и даље се не смањује интересовање за последице по локално становништво, преостале преживеле и нове генерације. 
Посебан проблем представља питање међународне одговорности за такве штете, јер оне не само да могу добити огромне размере и дуго времена остати неоткривене, већ је код њих често тешко доказати кривицу. Упркос прекиду даљег ширења нуклеарне индустрије, захтев за могућностима одлагања радиоактивног отпада повећао се због отпада који је настао гашењем великог броја реактора.

Живимо у доба опште несигурности која се проширила широм света. Десила се и нова расподела моћи. Ипак, очигледно је да свет не намерава да одустане од мирнодопског коришћења нуклеарне енергије, па је стога потребно усвојити боља решења у овој области, имајући у виду пропусте у претходном периоду.

Од прве употребе нуклеарног оружја у Јапану 1945. године, заштита од јонизујућег зрачења предмет је од изразитог интереса широм света, пошто су планета и цивилизација у опасности. Присутна је и сумња над оптимизмом који прати започето спровођење подухвата антиковид вакцинације, због појаве нових варијанти агресивног вируса (CAPC КоB 2).

Иако Петиција против нуклеарне енергије из 2000. године, настала на Шестој конференцији потписника Кјото Протокола, предвиђа изричито одбацивање нуклеарне енергије као одговор на проблем глобалног загревања, од нуклеарних електрана се још увек не одустаје. Антинуклеарни покрет у свету данас је веома јак и утиче на ограничавање броја нових и затварање постојећих електрана.

\section{Литература}

Анастасијевић, П., Мојовић, Љ., Развој нуклеарних електрана, „Нуклеарна енергија“, број 5, Београд, 1966.

Бубњевић, С., Несрећа која траје, Наука VII, Култура, уметност, наука, Политика, 1. мај 2021, Београд.

Драганић, И., Кроз свет радијација и радиоактивности: сто година атомске ере, Београд, 1996.

Greenpeace International Briefing on Radioactive Waste Dumping At Sea. The Contraversa over Ocean Dumping of Radioactive Wastes: The London Dumping Convention, Amsterdam, 1989. 
Јовановић, М., Нуклеарна дејства и човек: процена непосредних и позних последица озрачења, Београд, 1986,

Јовановић, М., Биомедицински и социолошки значај акциденталног озрачења људи, Београд, 1989.

Марковић, Стеван, Спаић, Рајко, „Радијација и здравље”, Друштво за биомедицинско инжињерство и медицинску физику СР Југославије, Аранђеловац, 2001.

Пешић, М., Велике силе се отимају за благо леденог острва, 04, spoljna \& politika.rs, 1, 2. и 3. мај 2021, Београд.

Preventing the transboundary movements of hazardous wastes in the Mediterranean region, VII Ordinary Meeting of the contracting Parties to the Convention for the Protection of the Mediterranean Sea against Pollution and its related protocols, Cairo, Egypt, 1991.

\title{
NUCLEAR SAFETY IN THE POST-SOVIET AND EUROPEAN AREA AFTER THE CHERNOBYL DISASTER
}

\begin{abstract}
The attitude toward the various uses of nuclear energy has become one of the major bones of contention in the foreign policy affairs and international activities of countries in general.

After the Chernobyl accident, the IAEA began work on all aspects of nuclear liability with the aim of improving basic conventions and establishing a broad accountability regime. When nuclear energy is concerned, ecological catastrophes recognize no borders and every pollution of the environment in one country or region would threaten the population of much broader areas. Nuclear energy, which is used today by over 50 countries, provides about $10 \%$ of the world's electricity from about 440 power reactors, while about 50 reactors are under construction. The effectiveness of legal and administrative solutions to the problems posed by the peaceful uses of nuclear energy will be heavily reliant on the appropriate adaptation of the relevant legal areas.
\end{abstract}

Keywords: safety, nuclear energy, Chernobyl, radiation, protection. 